\title{
KONSEP KELUARGA MASLLAHAH DALAM PERSPEKTIF QIRA'AH MUBADALAH DAN RELEVANSINYA DENGAN KETAHANAN KELUARGA DI MASA PANDEMI COVID-19
}

\author{
Ramdan Wagianto \\ Universitas Islam Zainul Hasan (UNZAH) Genggong Probolinggo \\ e-mail: ramdanwagianto@gmail.com

\begin{tabular}{|l|l|l|}
\hline Submit: 17-02-2021 & $\begin{array}{l}\text { Direvisi: 12-03-2021, } \\
\text { 10-04-2021 }\end{array}$ & Dipublish: 21-06-2021 \\
\hline
\end{tabular}

\begin{abstract}
Abstrack: This article discusses the concept of the maslahah family in the perspective of mubadalah and its relevance to family resilience during the Covid-19 pandemic. The maslah ah family is a family whose members provide each other with primary needs that include physical and mental needs, and each others give rights and obligations. This paper is a literature research, with the descriptive-qualitative as method research and qira'ah mubadalah as the approach. The results showed that the concept of maslahah family in the perspective of qira'ah mubadalah is that in principle it prioritizes the concept of mufa'alab (kesalingan), meaning that there are no superior and no inferior parties in the family. In this case the maslahah family indicators that can be displayed are at least several principles, namely the zawaj principle (prinsip saling berpasangan), the mu'adalah Principle (prinsip keadilan), the muwazanah principle (prinsip keseimbangan), the mu'awanah principle (prinsip saling menolong), the Principle of musyawarah, the Principle of taradhin min buma (prinsip kerelaaan), and the Principle of mu'asyarah bil ma'ruf (prinsip saling berkomunikasi/bergaul dengan baik). The author can conclude that the concept of the maslah ah family in the framework, of mubadalah is that it has quite significant relevance if it is applied by every family, especially in the current Covid-19 pandemic.
\end{abstract}

Kata kunci: Keluarga Maṣlaḥah, Qira’ah mubadalah, Ketahanan Keluarga, Covid-19

\section{PENDAHULUAN}

$I$

slam memandang bahwa perkawinan mempunyai kedudukan yang tinggi dalam kehidupan individual, kekeluargaan maupun kehidupan bangsa. Itulah kenapa Perkawinan dalam alQur'an disebut sebagai ikatan yang kuat/kokoh/mitsaqan galizhan (QS. AnNisa': 21). Dengan ikatan ini, setiap orang akan mengharapkan bahwa tujuan perkawinan untuk menjadikan keluarga yang maṣlaḥah, keluarga yang diliputi dengan rasa cinta (mawaddah), rasa kasih sayang (rahmah) dan ketenangan (sakinah) dapat terwujud (Mursalin, 2007: 1). Dalam rangka menciptakan keluarga yang tenteram, bahagia, dan sejahtera sebagaimana yang didambakan bukanlah persoalan yang mudah, karena terbentuknya keluarga adalah sebuah proses yang panjang dan melalui penyusuaian yang juga tidak mudah (Lestari, 2014: vi). Namun, semua itu dapat diusahakan oleh siapapun yang menghendakinya.

Sebuah keluarga dikatakan mașlaḥah jika setiap anggota keluarganya mampu memahami hak dan kewajiban (Sahal Mahfudh, 2001: 3). Keluarga maṣlahah juga dapat dikatakan sebuah keluarga yang dapat memenuhi kebutuhan primer (pokok) baik lahir maupun batin. Kebutuhan tersebut dapat diwujudkan dengan memperhatikan beberapa unsur, yaitu unsur suami yang baik (salih), istri yang baik (salihah), anak-anak yang baik (abrar) -dalam artian yang berkualitas, berakhlak karimah, sehat rohani dan 
jasmani, berkecukupan rizki (pangan sandang dan papan), serta memiliki lingkungan yang baik pula (Latif, 1982).

Islam telah memberikan gambaran tentang pondasi ideal untuk membangun keluarga yang mașlahah ini, yaitu sebuah keluarga yang dapat menciptakan suasana yang sakinah (tentram, tenang), penuh cinta (mawaddah) dan penuh kasih sayang (rahmah). Sebagaimana disebutkan dalam QS. Ar-Rum: 21.

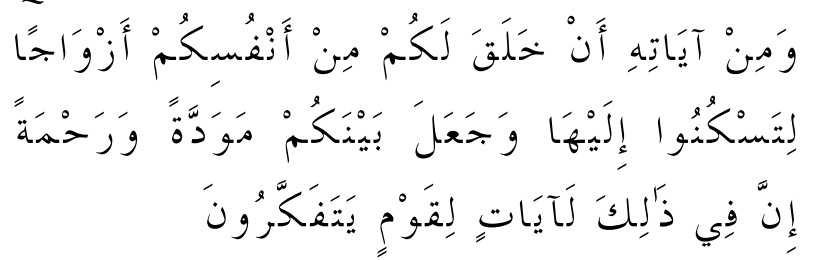

"Dan di antara tanda-tanda kekuasaan-Nya ialah Dia menciptakan untukmu isteri-isteri dari jenismu sendiri, supaya kamu cenderung dan merasa tenteram kepadanya, dan dijadikan-Nya diantaramu rasa kasih dan sayang. Sesungguhnya pada yang demikian itu benar-benar terdapat tanda-tanda bagi kaum yang berfikir."

Namun demikian, pada ranah praktiknya, di tengah situasi dimana hampir di semua aspek menjadi berdampak akibat pandemi Covid-19 ini. Di antara sektor yang berdampak adalah kesehatan, pendidikan, dan perekonomian. Akibatnya, banyak keluarga yang mulai goyah atas rumah tangganya, bahkan berujung pada perceraian. Aco Nur, Direktorat Jenderal Badan Pengadilan Mahkamah Agung Republik Indonesia (Dirjen Badilag MARI), mengatakan bahwa meningkatnya angka perceraian sebagai akibat dari pandemi covid, di mana hingga Juni 2020 telah mencapai 57 ribu kasus, dan mayoritas perceraian tersebut diajukan oleh pihak istri. Perceraian ini banyak dilatarbelakangi karena factor ekonomi (newsdetik, 2020). Selain itu, Sakroni, dalam sebuah Webinar $7^{\text {th }}$ International Academia Rountable Forum, menyoroti kasus perceraiann yang terjadi di Jawa Barat pada masa pandemi Covid-19. Ia menyebutkan bahwa penyebab umum perceraian pada masa pandemi ini adalah permasalahan ekonomi (banyak suami yang kehilangan pekerjaan), meningkatnya Kekerasan Dalam Rumah Tangga (KDRT), berubahnya pola komunikasi, dan faktor usia dalam membina rumah tangga. (Suspensos; Gambaran Kasus Perceraian di Jawa Barat, 2020).

Melihat banyaknya kasus perceraian di masa pandemi Covid-19 ini, menandakan bahwa ketahanan keluarga sudah mulai goyah, maka pada situasi yang sangat sulit seperti ini, rasanya penting untuk melihat dan mengkaji kembali bagaimana konsep membangun keluarga yang mașlaḥah menurut pandangan mubadalah, yaitu sebuah pandangan yang meniscayakan atas kesetaraan dan keadilan dalam membangun relasi antara laki-laki dan perempuan, dan saling menghadirkan kemanfaatan kepada keduanya tanpa ada unsur diskriminatif. Perspektif kesalingan ini bekerja sebagai cara pandang untuk menghormati martabat kemanusiaan setiap orang dan menghargai jati dirinya. Sikap seseorang yang tidak memandang orang lain lebih rendah dari dirinya. Maka dalam konteks berkeluarga akan timbul pandangan bahwa ruang publik tidak hanya untuk laki-laki semata, melainkan juga untuk perempuan. Begitu pula ruang domestik dalam keluarga tidak hanya diperuntukkan perempuan, tetapi berlaku juga untuk laki-laki. Cara pandang seperti ini mengarah pada relasi yang setara dan hubungan timbal balik antara laki-laki dan perempuan. Dengan demikian, ketika 
relasi yang setara sudah terbentuk, maka kemungkinan besar kerja sama di dalam keluarga akan terjadi, segala bentuk kekerasan dalam rumah tanggapun juga akan lebih mudah dihentikan, dan jalan menuju keadilan juga bisa lebih lempang (Kodir, 2019).

Berdasarkan penjabaran di atas, penulis akan memfokuskan pada dua pokok kajian dalam artikel ini, yaitu 1) bagaimana konsep keluarga mașlaḥah dalam perspektif qira'ah mubadalah, dan 2) Bagaimana relevansinya dengan ketahanan keluarga di masa pandemi.

\section{METODE PENELITIAN}

Metode penelitian yang digunakan dalam tulisan ini adalah deskripstif kualitatif, dengan qira'ah mubadalah sebagai pendekatannya. Penulis menggunakan metode analisis library research, yaitu penulis mengumpulkan data-data tertulis yang sesuai dengan masalah yang dikaji. Selanjutnya, penulis melakukan interpretasi terhadap data yang terkumpul. Tulisan ini bertujuan untuk mendeskripsikan dan membuat kesimpulan tentang konsep keluarga mașlahah dalam perspektif qira'ah mubadalah dan mendeskripsikan relevansinya dengan ketahanan keluarga di masa pandemi covid-19.

\section{KELUARGA MASLAHAH: SEBUAH TINJAUAN UMUM}

Kata maṣlahah (مصلحة) secara literal berasal dari bahasa Arab yang dalam Kamus al-Munawir dengan makna faidah (فائدة) yang berarti kemanfaatan, kemaslahatan, kepedulian, keuntungan, kebaikan, kesejahteraan. Kata mașlaḥah adalah bentuk masdar dari fi'il shalahayashluhu-shulhan/mashlahatan, yang artinya sama dengan kalimat ash-shalah atau seperti halnya lafaz al-manfa'at sama artinya dengan al-naf'u. kata mașlahah juga bisa dikatakan sebagai bentuk tunggal (mufrad) dari kata masalih (مصالح).

Ibnu Manzur dalam kamus lisan alArab menjelaskannya kedalam dua bentuk arti, yaitu mașlahah yang berarti shalah dan mașlahah yang berarti bentuk tunggal dari mashalih. Semua kata tersebut mengandung arti adanya manfaat baik secara asal maupun melalui proses, seperti menghasilkan kenikmatan dan faedah, ataupun pencegahan dan penjagaan, seperti menjauhi kemadaratan dan penyakit. Semua itu dapat dikatakan mașlahah (Syafe'i, 1999). Wahbah Zuhaili mengatakan bahwa mașlahah adalah segala sesuatu yang menguatkan dan menyempurnakan kehidupan manusia, serta memenuhi segala keinginan rasio dan syahwatnya secara mutlak. Pengertian ini jika ditinjau dari segi kebahasaan. Maṣlaḥah secara syara' (hakikat) dapat didefinisikan segala sesuatu yang menguatkan kehidupan di dunia dengan cara tidak merusaknya serta mampu menuai hasil dan beruntung di akhirat. (Az-Zuhaily, 1986: 799-800). Sementara itu, mașlaḥah dalam Kamus Besar Bahasa Indonesia, diartikan sesuatu yang mendatangkan kebaikan (keselamatan dan sebagainya), faedah, dan guna.

Dengan demikian, keluarga mașlahah dapat didefinisikan sebagai keluarga yang di dalamnya, antar anggota keluarganya, antara suami dan istri, antara orang tua dan anak, tercipta kondisi yang memberikan kemanfaatan, kepedulian, keuntungan kebaikan dan kesejahteraan. Keluarga mașlaḥah bisa juga dikatakan 
keluarga yang setiap anggota keluarganya baik, dan pada saat yang sama pula dapat memberikan kebaikan kepada masyarakat, baik masyarakat dalam scope kecil yakni keluarga maupun masyarakat luas (NUonline, 2019). Lebih lanjut, Kiai Sahal Mahfudh mengartikan keluarga mașlahah adalah keluarga yang setiap anggota keluarganya mampu memahami hak dan kewajibannya setara dengan pemahamannya atas hak dan kewajiban orang lain (Mahfudh, 2001: 3). Dengan kata lain, keluarga yang saling memenuhi hak dan kewajiban antara anggota satu dengan anggota lainnya. Artinya seorang anggota keluarga selain memahami hak dan kewajibannya sendiri juga mampu memahami hak dan kewajiban anggota lainnya.

Kemaslahatan sebuah keluarga akan terbentuk mana kala memenuhi ciri-ciri sebagai berikut (Najib et al., 2005), diantaranya adalah;

1. Suami-istri yang salih, yaitu suami/istri dapat mendatangkan manfaat dan faedah untuk dirinya, anak-anaknya dan lingkungan sekitarnya.

2. Anak-anaknya yang abrar, yaitu anakanak yang mempunyai berkualitas akhlak karimah, sehat jasmani dan rohaninnya, produktif dan kreatis sehingga mereka mempunyai sifat kemandirian.

3. Mempunyai tingkat pola bergaul yang baik, artinya pergaulan keluarga menjadi terarah, mempunyai lingkungan bergaul yang baik, dan bertetangga dengan baik.

4. Mempunyai kebutuhan hidup/rizki (sandang, pangan, dan papan) yang cukup.

Ungkapan di atas sesuai dengan hadis sebagaimana berikut ini;
اربع من سعادة المرء ان تكون زوجة صالحة واولاده ابرار وخلطاؤه صالحين و ان يكون رزقه في بلده Ada empat hal yang dapat menjadikan kebahagiaan seseorang, yaitu memiliki istri yang salihah, anak-anak yang berbakti, temanteman yang salih, dan tempat mencari rizkinya berada di negerinya (tempat kelahirannya). (HR. ad-Dailami)

Dalam konteks membentuk keluarga yang mașlaḥah, sebuah keluarga harus mempunyai tujuan (maqasid) yang hendak dicapai bersama. Dengan mengkaitkannya dengan maqasid asy syari'ah (tujuan-tujuan syari'ah) yang di dalamnya harus ada sisi hifz ad-din (perlindungan terhadap agama), hifz an-nafs (perlindungan terhadap jiwa), hifz an-nasl (perlindungan terhadap keturunan), hifz al-'aql (perlindungan terhadap akal), hifz al-mal (perlindungan terhadap harta), dan hifz al'ird (perlindungan terhadap penghormatan) (Asy-Syatibi, n.d.). Demikian pula dalam keluarga mașlahah, maka setidaknya terdapat komponenkomponen tersebut di atas.

Selain itu, Alisa wahid menyebutkan bahwa keluarga mașlaḥah setidaknya harus mempunyai pondasi, pilar, dinding dan atapnya. Ibarat sebuah rumah, maka bangunan keluarga harus dibangun di atas fondasi yang kokoh. Pondasi-pondasi tersebut diantaranya keadilan ( $m u$ 'adalah), kesalingan (mubadalah), dan keseimbangan (muwazanah). Sementara pilar keluarga yang dimaksud adalah perspektif zawaj, mitsaqan ghalidhzan, mu'asyarah bi al-ma'ruf, musyawarah, dan taradhin. Dengan pondasi yang kuat dan pilar yang kokoh, maka dinding yang mengitarinya juga akan menjadi kuat, dan bangunan keluarga maṣlaḥah akan terbentuk dengan memciptakan suasana jiwa yang Sakinah (menentramkan), 
mawaddah (penuh cinta), dan rahmah (kasih sayang). Kemudian bagian atap bangunan tersebut adalah prinsip kemaslahatan.

Lembaga Kemasalahatan Keluarga Nahdlatul Ulama (LKKNU) dan BKKBN mengatakan bahwa sebuah keluarga dikatakan mașlahah, jika keluarga tersebut dapat memelihara keseimbangan antara kebutuhan lahir dan kebutuhan batin, diantaranya 1) terpeliharanya keselamatan ibu dan anak, seperti terjaminnya keselamatan jiwa dan raga ibu selama hamil, melahirkan, dan menyusui serta terjaminnya keselamatan anak sejak dalam kandungan, 2) terpeliharanya keselamatan jiwa, Kesehatan jasmani dan ruhani anak serta tersedianya pendidikan bagi anak, dan 3) terjaminnya keselamatan agama orang tua yang dibebani kewajiban menyediakan kebutuhan hidup keluarga (Ensiklopedi NU, n.d.).

\section{KONSEP QIRA'AH MUBADALAH}

Kata mubadalah (مُبَادَلَّة) secara bahasa merupakan bentuk Masdar dari fi' il madhi باَدَل (ba-da-la) yang berarti mengganti, mengubah, dan menukar (timbal balik). Menurut kaidah sorfiyah, akar kata ini mengikuti wazan فَاعَلَ yang mempunyai faidah لِمُشَارَكَة بَيْنَ الاثْنَيْن (limusyarakah baina al-isnaini) yaitu interaksi antara dua orang, atau bisa juga dikembalikan kepada bentuk (mufa'alah/مُفَاعَلَة) yaitu makna kesalingan. Jadi, kata mubadalah dapat diartikan saling mengganti, saling mengubah, atau saling menukar satu sama lain. Di dalam al-Qur'an, akar kata tersebut digunakan sebanyak 44 kali dengan berbagai bentuk kata yang mempunyai makna seputar itu.

Kamus al-mu'jam al-wasith mengartikan kata mubadalah dengan tukar menukar yang bersifat timbal balik antara dua pihak (Syauqi, 2011). Selain itu, kamus Arab-Inggris Al-Mawarid, karya Dr. Rohi Baalbaki, mengartikan kata mubadalah dengan muqabalah bi al-mitsl, yaitu menghadapkan sesuatu dengan padanannya, yang kemudian diterjemahkan ke dalam bahasa Inggris dengan beberapa makna, diantaranya reciproty, reciprocation, repayment, requital, paying back, returning in kind or degree (Baalbaki, 1995). Sementara dalam Kamus Besar Bahasa Indonesia (KBBI), kata "kesalingan" digunakan untuk hal-hal yang menunjukkan makna timbal balik.

Merujuk beberapa makna di atas, kemudian istilah mubadalah dikembangkan oleh Qadir untuk sebuah perspektif dan pemahaman dalam relasi tertentu antara dua pihak, yang mengandung nilai dan semangat kemitraan, kerja sama, kesalingan, timbal balik, dan prinsip resiprokal (Kodir, 2019). Konteks relasi dalam pembahasan ini adalah berlaku secara umum, seperti negara dan rakyat, majikan dan buruh, orang tua dan anak, guru dan murid, mayoritas dan minoritas, laki-laki dan laki-laki atau perempuan dan perempuan, laki-laki dan perempuan, baik dalam skala local maupun global. Namun, dari beberapa jenis relasi tersebut, fokus dalam pembahasan tulisan ini adalah relasi dalam keluarga, yaitu relasi perempuan dan laki-laki. Konsep mubadalah dalam pembahasan tulisan ini hanya dengan dua pengertian saja, yaitu relasi kemitraan perempuan, dan bagaimana sebuah teks Islam mencakup perempuan dan laki-laki sebagai subjek dari makna yang sama. 
Di dalam al-Qur'an terdapat banyak surat dan ayat yang mempunyai makna mubadalah, diantaranya sebagaimana yang akan penulis sajikan berikut ini, misalnya pada QS. al-Hujurat [49]; 13, dan QS. alMaidah (5) : 2.

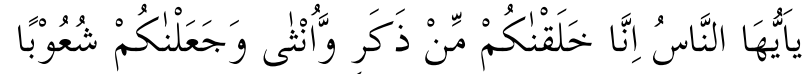

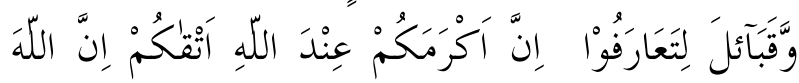

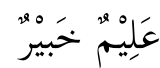

"Wahai manusia! Sungguh, Kami telah menciptakan kamu dari seorang laki-laki dan seorang perempuan, kemudian Kami jadikan kamu berbangsa-bangsa dan bersuku-suku agar kamu saling mengenal. Sesungguhnya yang paling mulia di antara kamu di sisi Allah ialah orang yang paling bertakwa. Sungguh, Allah Maha Mengetahui, Mahateliti." (QS. al-Hujurat [49]: 13).

Kata "ta'arafu" pada ayat tersebut merupakan bentuk kata kesalingan (mufa'alah) dan kerja sama (musyarakah) dari kata 'arafa yang berarti saling mengenal satu sama lain. Artinya satu pihak mengenal pihak lain, dan begitu pun sebaliknya.

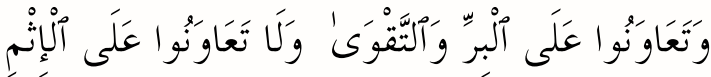

$$
\begin{aligned}
& \text { وَآلْعُوْونِ }
\end{aligned}
$$

“... Dan tolong-menolonglah kamu dalam (mengerjakan) kebajikan dan takwa, danjangan tolong-menolong dalam berbuat dosa dan pelanggaran...." (QS. al-Maidah [5]: 2).

Kata "ta'awanu" juga menggunakan bentuk yang sama sebagaimana kata "ta'arafu". Kata ta'awanu berarti saling tolong-menolongllah kalian semua. Ayatayat tersebut memberi indpirasi yang jelas mengenai pentingnya relasi kerja sama dan kesalingan antarmanusia. Termasuk di dalamnya adalah relasi antara laki-laki dan perempuan.
Pada dasarnya prinsip mubadalah ini adalah menekankan pada kemitraan atau kesalingan antara laki-laki dan perempuan dalam kehidupan. Dengan prinsip ini, sebagaimana laki-laki yang ingin diakui keberadaannya, dihormati pilihannya, didengar suaranya, dan dipenuhi segala keinginannya, maka demikian pula perempuan, berhak untuk mendapatkan perlakuan yang sama. Perspektif kesalingan ini akan membuahkan cara pandang yang memanusiakan manusia laki-laki dan perempuan. Sebuah cara pandang yang akan mengarah pada relasi yang setara dan timbal balik untuk kebaikan hidup antara laki-laki dan perempuan, sebagai modal mencapai kesejahteraan laki-laki dan perempuan dalam kehidupan, baik diranah domestik maupun publik (Kodir, 2019).

Cara pandang mubadalah mencerminkan suatu kesetaraan dan keadilan dalam relasi antara laki-laki dan perempuann, yang kemudian dapat mendorong sikap kerja sama yang partisipatif, adil dan memberi manfaat kepada keduanya tanpa diskriminatif. Ruang publik tidak hanya diperuntukkan bagi kaum laki-laki, sementara ruang domestik pun juga tidak hanya dibebankan kepada kaum perempuan saja. Partisipasi keduanya disemua ruang, publik dan domestik, harus dibuka seluasluasnya secara adil sekalipun dilakukan dengan cara, model, dan pilihan yang berbeda-beda (Werdiningsih, 2020). Bentuk partisipatif dari kedua belah pihak ini semata untuk memastikan penghormatan kemanusiaan benar nyata hadir dalam dua ranah. Hal ini juga untuk memastikan hadirnya prinsip-prinsip ta'awun (saling menolong), tahabub (saling mencintai), tasyawur (saling memberi 
pendapat), taradhin (saling rela), dan ta'ashur bil ma'ruf (saling memperlakukan secara baik) dalam relasi laki-laki dan perempuan, baik di ranah domestik maupun publik.

Konsep mubadalah ini, yang kemudian dijadikan sebagai perspektif dan metode, tidak berangkat dari ruang kosong, melainkan terdapat penyebab yang melatarinya. Setidaknya terdapat dua factor penyebabnya, yaitu factor sosial dan bahasa (Kodir, 2019). Factor sosial berkaitan dengan cara pandang masyarakat yang lebih banyak memposisikan pengalaman laki-laki dalam memaknai agama. Dalam artian yang lain, dalam menafsirkan teks-teks keagamaan lebih mengutamakan sudut pandang laki-laki daripada perempuan. Kondisi seperti tidak bisa dipungkiri adanya. Sedangkan factor Bahasa lebih berkaitan dengan struktur Bahasa Arab, baik itu yang berkaitan tentang pembedaan laki-laki dan perempuan, isim (kata benda), fi'il (kata kerja), dhamir (kata ganti, baik mufrad ataupun jama'), dan aturan-aturan lain yang tercakup dalam kajian Bahasa Arab.

\section{KONSEP KELUARGA MASLLAHAH DALAM PERSPEKTIF QIRA'AH MUBADALAH}

Ibarat seorang yang ingin sukses dalam menjalankan sebuah instansi atau organisasi tertentu, maka seseorang itu harus mempunyai visi dan misi yang jelas. Hal ini bertujuan supaya tujuan, cita-cita dan harapan yang ingin dicapai dari sebuah instansi atau organisasi dapat berjalan sesuai yang diinginkan. Demikian pula instansi atau organisasi yang bernama keluarga, maka harus mempunyai visi dan misi yang jelas.
Dalam konteks visi dan misi disini adalah bahwa sebuah keluarga diharapkan mempunyai pilar dan prinsip-prinsip untuk membangun keluarga mașlaḥah.

Adapun pilar dan prinsip dari keluarga mașlahah dapat penulis jabarkan sebagai berikut;

\section{Prinsip Zawaj}

Prinsip keluarga mașlaḥah yang pertama yaitu prinsip berpasangan, yang dalam al-Qur'an dibahasakan dengan kata "zawj". Gambaran prinsip ini, menurut catatan Kodir yang dirujuknya dari kitab Al-Mu'jam al-Mufahras li Alfazh al-Qur'an karya Fuad Abdul Baqi, bahwa kata "zawj" ini berada di 17 tempat di dalam al-Qur'an, diantaranya 7 tempat tanpa imbuhan (jو), 4 tempat dengan tambahan kata ganti laki-laki (زوج)( (زوج), 2 tempat dengan imbuhan kata ganti orang ketiga tunggal untuk laki-laki (زوجه), dan 4 tempat dengan imbuhan kata ganti tunggal untuk perempuan. Pada semua tempat tersebut, kata "zawj" bermakna pasangan.

Sebagaimana yang penulis sebutkan pada bagian sebelumnya, bahwa pespektif mubadalah ini terjadi salah satunya karena adanya faktor sosial. Secara faktual dapat kita jumpai bahwa di dalam keluarga yang ada di lingkungan sekitar kita, disadari atau tidak, masih terlihat salah satu diantara keluarga yang lebih mendominasi dari pada anggota yang lainnya. Hal ini mungkin juga karena factor dari budaya yang sudah lama mentradisi, misal budaya patrilineal atau matrilineal. Jika kita kembalikan pada prinsip ini, maka sesuatu yang berpasangan, tidak seharusnya ada salah satu diantaranya yang merasa mendominasi. 
Sebagai contoh prinsip ini adalah alQur'an surah ar-Rum ayat 21;

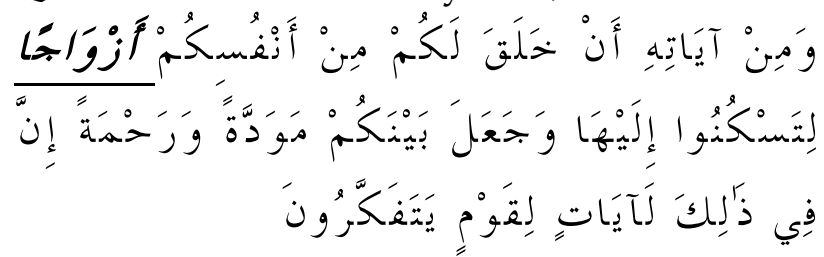

"Dan di antara tanda-tanda kekuasaan-Nya ialah Dia menciptakan untukmu isteri-isteri dari jenismu sendiri, supaya kamu cenderung dan merasa tenteram kepadanya, dan dijadikan-Nya diantaramu rasa kasih dan sayang. Sesungguhnya pada yang demikian itu benar-benar terdapat tanda-tanda bagi kaum yang berfikir."

Maka dalam persepktif mubadalah, untuk menciptakan keluarga yang mașlaḥah, kata "azwajan" pada ayat tersebut dapat dimaknai dengan pasangan. Artinya suami pasangan istri dan juga sebaliknya. Layaknya sebagai pasangan, maka keluarga semestinya mempunyai sikap yang saling melengkapi satu dengan lainnya. Sebagai pasangan, sang istri melengkapi keberadaan sang suami, begitu juga suami melengkapi keberadaan istri. Dalam masyarakat jawa dikenal dengan istilah "garwo" (sigaraning nyowo-separuh nyawa/jiwa), yaitu sebuah filosofi bahasa untuk menggambarkan bahwa istri adalah belahan jiwa suami, dan suami belahan jiwa istri.

\section{Prinsip Mu'adalah}

Prinsip mu'adalah berbicara tentang prinsip keadilan. Adil bukan hanya berarti persamaan atau hanya menempatkan sesuatu pada tempatnya atau tidak berpihak kepada orang-orang tertentu. Melainkan bagaimana setiap orang bisa menempatkan bahwa setiap orang mempunyai nilai. Berpegangan pada perspektif mubadalah, prinsip keadilan harus dimaknai bahwa setiap anggota keluarga harus diposisikan mempunyai nilai semuanya, sehingga tidak ada anggota yang merasa dianggap tidak berguna eksistensinya di dalam keluarga atau tidak ada perlakuan yang nir-keadilan. Dengan prinsip mua'adalah ini, setiap anggota keluarga akan mempunyai kesempatan yang sama sesuai dengan porsinya masing-masing untuk bisa mengembangkan diri tanpa membedakan status gender atau jenis kelamin (Yusdani \& Muntoha, 2013: 187) atau dengan perkataan lain bahwa keadilan di dalam keluarga itu sifatnya proporsional.

Alisa Wahid menuturkan bahwa terdapat banyak tempat, termasuk di Indonesia, yang masih memperlakukan berbeda antara anak laki-laki dan perempuan. Ia mencontohkan bahwa sering kali anak laki-laki lebih berhak daripada anak perempuan atas Pendidikan tinggi. Alasannya adalah anak perempuan nantinya akan menjadi ibu dan menjadi seorang ibu tidak membutuhkan pendidikan yang tinggi. Kondisi seperti ini faktanya juga terjadi di lingkungan penulis, bahwa tidak banyak anak perempuan yang melanjutkan pendidikan hingga Perguruan Tinggi. Alasan yang paling mendasarpun juga sama seperti yang disampikan Alisa. Tentu kondisi seperti ini tidak bisa dilanjutkan, karena tidak ada keadilan untuk anak-anaknya (UNINUS, 2020). Maka dalam keluarga yang mașlahah, dengan pertimbangan mubadalah, dalam konteks ini, semua anak-anak di dalam keluarga sudah semestinya diperlakukan yang sama.

Prinsip mu'adalah ini banyak disebutkan di dalam al-Qur'an meskipun tidak secara langsung dikhususkan untuk persoalan-persoalan yang menyangkut 
keluarga. Namun setidaknya bisa dijadikan sebagai pijakan yang kemudian bisa diterapkan oleh masing-masing anggota keluarga. Di antara ayat-ayat itu adalah sebagi berikut

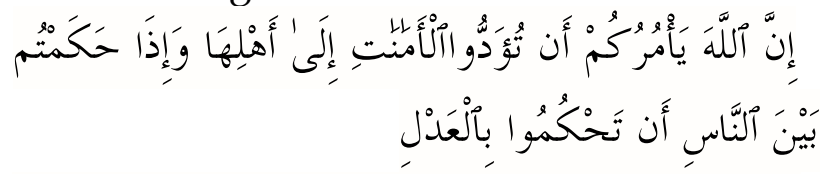

"Sesungguhnya Allah menyuruh kamu menyampaikan amanat kepada yang berhak menerimanya, dan (menyuruh kamu) apabila menetapkan hukum di antara manusia supaya kamu menetapkan dengan adil." (QS. An-Nisa': 58)

Ayat lainnya adalah QS. An-Nisa (16): 90

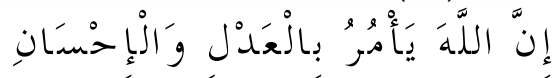

"Sesungguhnya Allah menyuruh (kamu) berlaku adil dan berbuat kebajikan"

Dari kedua ayat di atas bahwa khitob yang dituju adalah semua orang, baik laki-laki ataupun perempuan, hendaknya untuk bersikap adil. Pada ayat pertama misalnya, bahwa agar menyerahkan setiap perkara kepada ahlinya, dan hal ini dapat di-tamsil-kan kepada anak yang mempunyai kemampuan untuk mendapat Pendidikan ke jenjang yang lebih tinggi tanpa membedakan jenis kelamin atau gender (Nasution, 2013: 76).

\section{Prinsip Muwazanah}

Prinsip muwazanah menggambarkan adanya keseimbangan di dalam keluarga. Dikatakan seimbang jika antara satu dengan yang lainnya tidak ada ketimpangan. Maka sebenarnya prinsip ini masih terdapat keterkaitannya dengan prinsip sebelumnya, yaitu prinsip mu'adalah. Artinya jika setiap anggota telah menerapkan keadilan di dalam keluarga, maka bisa dipastikan prinsip ini bisa terjadi.

Dalam perspektif mubadalah yang menunjukkan prinsip resiprokal, bahwa masing-masing anggota keluarga untuk saling berusaha menciptakan keseimbangan di dalam keluarga. Oleh karena itu, ketika salah satu anggota keluarga, misal istri sedang sakit sehingga urusan domestik di dalam keluarga tidak tertangani dengan baik, maka supaya keseimbangan di dalam keluarga tetap berjalan, suami dan/atau dibantu oleh anak menyelesaikan secara Bersama-sama tugas dan peran dari sang istri.

Keseimbangan di dalam keluarga dapat diwujudkan dengan memenuhi hak pribadi, hak keluarga, hak kerja dan hak sosial. Bapak misalnya harus dapat memenuhi kebutuhan dan hak diri pribadinya, hak istrinya, hak anaknya, hak pekerjaannya, dan hak sosialnya. Tidak boleh ada yang tidak mendapatkan perhatian. Demikian pun ibu harus dapat memenuhi kebutuhan atau hak diri pribadi, hak suaminya, hak anaknya, hak kerjaannya dan hak sosial. Jika salah satu saja dari hak-hak di atas tidak terlaksana, maka ini menunjukkan sebuah ketimpangan, dan ketimpangan itu menunjukkan sebuah ketidakadilan.

Dengan demikian, untuk menjaga prinsip ini supaya berjalan secara continue harus dibarengi oleh prinsip selanjutnya, yaitu prinsip mu'awanah.

\section{Prinsip Mu'awanah}

Prinsip mu'awanah adalah prinsip kemitraan atau partnership. Dalam konteks keluarga, suami dan istri adalah partner dalam menjalankan visi dan misi kehidupan keluarga. Layaknya sebagai seorang partner atau mitra, dalam pandangan mubadalah, mereka harus saling melengkapi dan saling membutuhkan yang mensyaratkan hubungan mitrasejajar. Maksudnya adalah tidak ada dari satu pihak yang 
lebih penting dari yang lainnya, tidak ada yang lebih tinggi, tidak ada labih berkuasa dari yang lain. Seorang partner yang baik adalah partner yang selalu menghormati, saling menerima dan memberi, saling nasihat dan menasihati, dan saling sabar dalam mengarungi berbagai cobaan hidup di dalam berumah tangga.

Kaitannya dengan prinsip ini, alQur'an telah menggambarkannya dalam beberapa ayat, diantaranya adalah;

Ayat pertama,

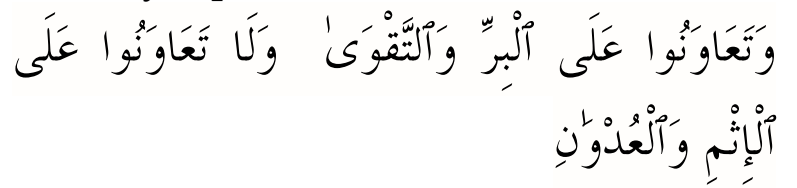

“... Dan saling tolong-menolonglah kamu dalam (mengerjakan) kebajikan dan takwa, danjangan tolong-menolong dalam berbuat dosa dan pelanggaran...." (QS. al-Maidah [5]: 2).

Ayat kedua,

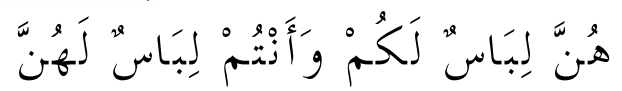

"...mereka adalah pakaian bagimu, dan kamupun adalah pakaian bagi mereka..."

Pada ayat pertama, sebagai seorang partner hidup, maka suami istri selayaknya menunjukkan sikap saling tolong-menolong, saling membantu dalam menjalankan perannya di dalam keluarga. Sementara ayat kedua menjelaskan bahwa istri adalah pakaian suami, dan suami adalah pakaian istri. Demikianlah jika ayat ini dimaknai secara mubadalah. Pakaian dalam ayat ini merupakan tamsil, yang jika dilihat dari segi fungsinya yaitu sebagai pelindung, penutup. Pakaian sebagai pelindung, ingin menggambarkan bahwa suami istri harus saling melindungi dari berbagai hal yang dapat menggoyahkan keluarga. Pakaian sebagai penutup, bisa diartikan suami istri saling berusaha untuk menutupi kekurangan atau aib masing-masing pasangannya.
Selanjutnya, sebagai implikasi prinsip muawanah atau kemitraan ini, setidaknya akan muncul sikap 1) saling mengerti; mengerti latar belakang pribadi pasangan masing-masing dan mengerti diri sendiri, 2) saling menerima kelebihan dan kekurangan, 3) saling mengormati setiap perkataan, perasaan, bakat dan keinginan, 4) saling mempercayai, dan 5) saling mencintai dengan cara yang lemah lembut dalam pergaulan dan pembicaraan, menunjukkan perhatian kepada suami/istri, bijaksana dalam pergaulan, menjauhi sikap egois, tidak mudah tersinggung, dan menunjukkan rasa cinta (Efendi \& Khamami, 1999: 346347).

\section{Prinsip Musyawarah}

Prinsip ini menggambarkan bagaimana suami, istri dan anggota keluarga yang lain saling menunjukkan sikap dan perilaku untuk selalu berembuk dan bertukar pendapat dalam memutuskan sesuatu, dan tidak saling memaksakan kehendaknya. Masingmasing pasangan harus open minded terhadap pendapat dan pandangan pasangannya (Yusdani, 2015a: 186). Mengajak bicara pasangan adalah salah satu bentuk pengakuan dan penghargaan terhadap harga diri dan kemampuannya. (Kodir, 2013: 355). Semua yang berkaitan dengan persoalan keluarga dan rumah tangga sudah semestinya untuk diselesaikan secara tasyawurin (saling berembug) bersama. Ketika sudah dimusyawarahkan, maka setiap anggota sudah selayaknya menjalankan hasil keputusan bersama dengan rasa kerelaan.

Ada banyak dalil yang menjelaskan bahwa dalam setiap perkara harus diselesaikan secara bermusyawarah, salah satu contoh diantaranya adalah urusan 
penyapihan terhadap anak yang dijelaskan dalam QS. Al-Baqarah [2]: 233,

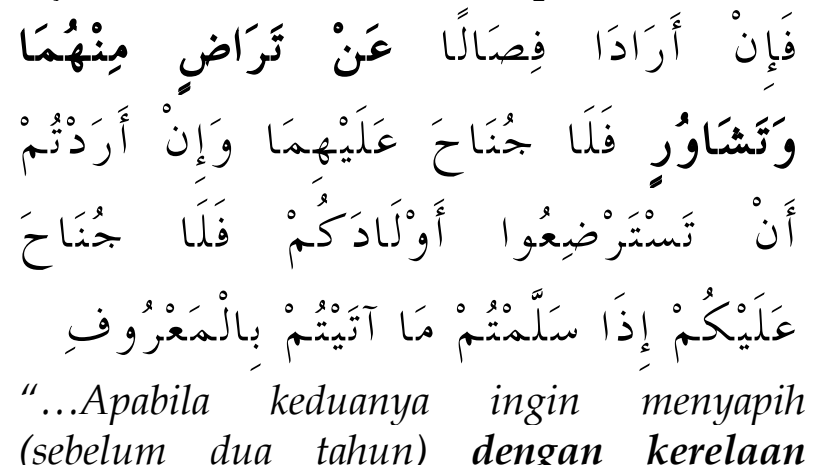

keduanya dan permusyawaratan, maka tidak ada dosa atas keduanya. Dan jika kamu ingin anakmu disusukan oleh orang lain, maka tidak ada dosa bagimu apabila kamu memberikan pembayaran menurut yang patut..."

Pada ayat ini terlihat jelas bahwa untuk perkara penyapihan anak yang belum berusia dua tahun harus ada sikap taradhin -sikap saling rela (kerelaan)- antara ayah/ibu atau suami/ istri, tidak ada paksaan dari siapapun, serta melalui proses tasyawur, yaitu musyawarah atau diskusi untuk mendapatkan keputusan yang terbaik (Shihab, 2005: 505).

\section{Prinsip Taradhin min huma}

Prinsip ini menggambarkan adanya kerelaan atau penerimaan dari kedua pihak, suami dan istri saling merasa nyaman dan memberikan kenyamanan. Seseorang yang di dalamnya ada rasa kerelaan, maka tidak ada sedikitpun penolakan atau ganjalan di dalam hatinya. Keluarga yang anggotanya diliputi dengan rasa kerelaan, menciptakan lingkungan yang penuh dengan kebahagiann dan rasa cinta kasih akan senantiasa terwujud. Sebagai contoh, dalam persoalan penyapihan saja sebagaimana QS. Al-Baqarah: 233membutuhkan kerelaan suami dan istri, apalagi untuk persoalan lainnya, tentu membutuhkan ketersalingan yang lebih intens.

Oleh karena itu, dalam konteks mencari kerelaan di dalam keluarga, seyogyanya dimaknai secara mubadalah, supaya tercipta kehidupan surgawi yang senantiasa menciptakan ketenangan dan kenyamanan. Seperti misal, hadis yang menyatakan bahwa seorang istri akan masuk surga jika memperoleh kerelaan dari suami. Secara mubadalah hadis ini juga bermakna bahwa suami akan masuk surg jika mempereloh kerelaan dari istri. Hal ini disebabkan suami dan istri pada dasarnya harus selalu saling mengupayakan kerelaan dari pasangannya.

\section{Prinsip Mu'asyarah bil $m a^{\prime}$ 'ruf}

Menciptakan relasi yang baik antara suami, istri dan anggota keluarga lainnya sudah menjadi hal yang semestinya dilakukan oleh setiap keluarga yang menginginkan kehidupan keluarga yang penuh dengan Sakinah (ketenangan), mawaddah (cinta) dan rahmah (kasih sayang). Prinsip mu'asyarah bil ma'ruf inilah yang harus menjadi perhatian oleh semua anggota keluarga. Kata mu'asyarah bil ma'ruf ini sebenarnya sudah mengandung makna mufa'alah atau kesalingan, resiprokal dan timbal balik.

Ayat al-Qur'an yang menjadi pondasi prinsip ini adalah QS. An-Nisa [4]: 19;

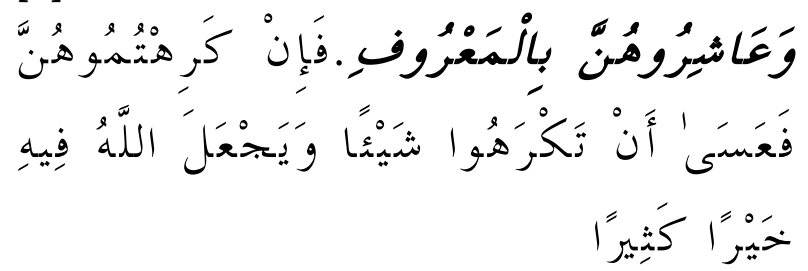

“...Dan perlakukanlah mereka dengan baik Kemudian bila kamu tidak menyukai mereka, (maka bersabarlah) karena mungkin 
kamu tidak menyukai sesuatu, padahal Allah menjadikan padanya kebaikan yang banyak..."

Oleh karena ayat ini secara eksplisit sudah menjelaskan makna resiprokal, maka meskipun ayat ini ditujukan kepada para suami untuk berbuat baik kepada istri, berlaku sebaliknya juga, istri juga berperilaku baik kepada suaminya. Dengan demikian, ayat di atas dapat dimaknai secara mubadalah sebagai berikut;

"Dan perlakukanlah (wahai lakilaki/suami dan perempuan/istri) pasanganmu dengan baik. Kemudian bila kamu tidak menyukai mereka, (maka bersabarlah) karena mungkin kamu tidak menyukai sesuatu, padahal Allah menjadikan padanya kebaikan yang banyak..."

Khairuddin menyebutkan bahwa ayat ini bersifat normative-universal, artinya berlaku untuk semua orang, baik muslim maupun muslimah. Seseorang dalam kondisi apapun diperintahkan untuk saling berhubungan (berkomunikasi) dengan baik (Nasution, 2018: 37). Segala kebaikan harus secara nyata diperoleh bersama dalam kehidupan laki-laki sebagai suami/ ayah/anak dan perempuan sebagai istri/ibu/anak serta dilakukan juga sebagai bentuk tanggung jawab Bersama.

Secara mubadalah, norma mu'asyarah bil ma'ruf antara suami dan istri adalah etika puncak dan ruh bagi seluruh ajaran dan aturan Islam. Dengan perspektif mubadalah ini, setidaknya dapat memastikan bahwa perempuan dan lakilaki memperoleh kebaikan, dan harus dijadikan sebagai indikator ketercapaian tujuan-tujuan hukum Islam (maqasid alsyari'ah al-khamsah) dalam keluarga. Dalam konteks perlindungan jiwa (hifz alnafs) misalnya, keluarga memastikan bahwa hak hidup dan peningkatan kualitas hidup antara laki-laki dan perempuan di dalam keluarga dapat terpenuhi. Demikian pula dengan perlindungan terhadap agama dan ibadah (hifz al-din), akal pikiran dan pengetahuan (hifz al-'aql), keturunan dan hak-hak reproduksi (hifz al-nasl), serta harta dan kepemilikan (hifz al-mal), harus diapastikan dapat mencakup perempuan dan laki-laki dan perempuan sebagai implementasi mubadalah dalam norma mu'asyarah bil ma'ruf. (Kodir, 2019: 332)

\section{KELUARGA MASLAHAH DAN KETAHANAN KELUARGA DI MASA PANDEMI COVID-19}

Ketahanan keluarga di masa pandemi COVID-19 benar-benar sedang diuji. Sebagaimana pada bagian sebelumnya, penulis ulas sedikit tentang hal ini, bahwa melemahnya ketahanan keluarga ini dibuktikan oleh pengajuan perceraian di Pengadilan-pengadilan Agama di Indonesia yang terjadi secara signifikan. Perceraian dalam Islam memang merupakan sesuatu yang tidak dilarang, namun ia termamsuk perkara yang paling dibenci oleh Allah SWT (abgad al-halal ilallahi at-thalaq). Namun demikian, konflik di dalam keluarga merupakan sesuatu hal yang tidak dapat dipungkiri eksistensinya, sehingga hanya personal yang mampu mengendalikan dan mempunyai managemen konflik yang baik yang dapat menyelamatkan biduk rumah tangganya.

Apapun persoalan yang terjadi di dalam rumah tangga yang pada puncaknya terjadi sebuah perceraian, masing-masing pasangan harus selalu mempunyai pedoman atau pegangan dar'ul mafasid wa jalb al-masalih (menolak kemafsadatan dan mendatangkan 
kemaslahatan). Dengan perceraian apakah akan menyebabkan kemaslahatan untuk keberlangsungan hidupnya, termasuk keberlangsungan anak-anaknya, atau apakah malah mendatangkan kemafsadatan. Maka dalam persoalan yang demikian seharusnya setiap orang di dalam keluarga mempu memikirkannya. Apalagi dalam situasi pandemi Covid-19 seperti ini, yang hampir semua keluarga terdampak olehnya.

Untuk menciptakan keluarga atau hanya untuk mempertahankan keluarga yang mașlaḥah dalam kondisi ketahanan sebuah keluarga sedang mengalami "kerapuhan" menjadi tantangan tersendiri, namun Ketika seseorang mempunyai pemahaman yang baik tentang konsep mubadalah di dalam keluarga, akan meminimalkan resiko terjadinya perceraian. Meskipun, sekali lagi penulis katakan, bahwa problem di dalam keluarga tidak bisa dipungkiri, tetapi jika problem itu dapat dipecahkan secara konsep keluarga maṣlahah dengan sudut pandang mubadalah -sebagaimana penulis jelaskan sebelumnya- akan menjadikan keluarga lebih dewasa dalam menyikapinya.

Dalam kondisi ketahanan keluarga yang sudah mulai goyah di masa pandemi seperti ini dan untuk tetap menjaga keluarga mașlahah, menurut penulis ada beberapa aspek yang sekiranya perlu menjadi pertimbangan, tentu masih dalam kerangka mubadalah, diantaranya adalah 1. Aspek spiritualitas

Aspek ini penulis sebutkan pertama pada konteks ini, karena kondisi pandemi seperti ini disadari atau tidak kondisi batiniah anggota keluarga, terutama suami dan istri, merasakan ketidaktenangan. Hal ini disebabkan situasi dan kondisi keluarga yang mengalami perubahan, semuanya dituntut untuk beradaptasi dengan kebiasaan baru yang dalam keadaan normal yang mungkin jarang mereka rasakan. Maka dalam kondisi yang serba tidak tenang ini, setiap anggota keluarga, terutama suami dan istri, setidaknya dapat meningkatkan spiritualitasnya, mendekatkan diri kepada Allah Swt. Dengan adanya ketenangan seperti itu, hati (qalb) dan pikiran (fiqr) ada ketenangan, maka akan dapat berfikir pula secara tenang.

Kondisi seperti ini sebagaimana Allah Swt firmankan di dalam alQur'an surah ar-Ra'du ayat 28,

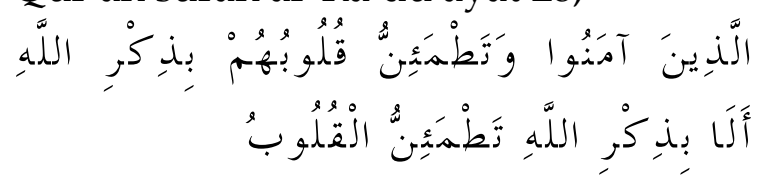

"(yaitu) orang-orang yang beriman dan hati mereka manjadi tenteram dengan mengingat Allah. Ingatlah, hanya dengan mengingati Allah-lah hati menjadi tenteram."

Segala persoalan datanganya dari Allah Swt, maka sudah semestinya dikembalikan kepada-Nya. Maka dengan mengingatnya, mendekatkan diri kepada-Nya dengan melalui berbagai aktivitas yang sifatnya ubudiyah yang menjadikan hati merasa tenang, segala kegundahan dan kegelisahan berubah menjadi kebahagiaan. Suami dan istri sebagai partner atau mitra hidup secara Bersama-sama untuk membangun nilai-nilai spiritualitas di dalam keluarga. Dalam konsep mubadalah, dalam aspek spiritual seperti ini, menjadi sebuah keniscayaan suami dan istri berjalan secara beriringan untuk meningkatkan kualitas keluarga terutama di saat-saat sulit seperti ini. Sebagaimana Alisa mengibaratkan 
hubungan suami istri seperti sepasang sandal jepit, dimana jika kaki kanan di depan maka sudah mestinya kaki kiri di belakang, begitu pula sebaliknya. Dalam konteks spiritual pun juga demikian, semuanya (suami dan istri) memberikan dorongan untuk saling menguatkan, ketika kondisi suami sedang merasakan ketidak tenangan maka istri berusaha untuk menciptakan ketenangan di dalam keluarga, dan begitu pula sebaliknya. Dengan demikian, menanamkan prinsip-prinsip keluarga mașlahah dalam konteks mubadalah dalam kondisi pandemi seperti ini sangat dibutuhkan.

2. Aspek psikologis

Kondisi psikis tentu juga mengalami gangguan, stress yang disebabkan oleh keadaan yang diluar dari kebiasaan (new normal) masingmasing anggota keluarga. Maka dalam kondisi seperti ini, di tengah pergolakan dan perubahan yang signifikan akibat pandemi, keluarga harus mempunyai kelentingan dalam mengadapi perubahan tersebut. Wals mengatakan bahwa dengan kelentingan ini, distress akan dipandang sebagai tantangan bagi keluarga, tidak menganggap sebagai sesuatu yang merusak, serta melihat potensi yang dimiliki oleh keluarga untuk terus tumbuh dan melakukan perbaikan (Wals, 2006). Kunci bagi kelentingan keluarga adalah terdapatnya system keyakinan, pola pengorganisasian keluarga, dan proses kemonukasi dalam keluarga. Sistem keyakinan ini adalah inti dari kelentingan keluarga yang mencakup tiga aspek, yaitu kemampuan untuk memaknai penderitaan, berpandangan positif yang melahirkan sikap optimis, dan keberagaman. Sedangkan pola pengorganisasian keluarga mengindikasikan adanya struktur pendukung bagi integrasi dan adaptasi dari anggota keluarga. Oleh karena itu, keluarga harus memobilisasi sumber dayanya dan melakukan reorganisasi untuk menyesuaikan dengan perubahan yang terjadi. Ada tiga aspek tentang pola pengorganisasian, yaitu fleksibilitas, keterhubungan (connectedness), serta sumber daya sosial dan ekonomi. Sementara itu, aspek komunikasi menurut penulis menjadi puncak dari pada kelentingan keluarga. Dengan komunikasi yang baik, segala persoalan sesulit apapun akan mudah diketemukan solusi pemecahannya.

$$
\text { Selanjutnya, }
$$

komunikasi dikatakan menjadi penentu bagi kelentingan keluarga, Ketika keluarga mempunyai kemampuan untuk memperjelas pesan yang memungkinkan anggota keluarga dalam memperjelas situasi krisis, keluarga mempunyai kemampuan untuk mengungkapkan perasaan untuk saling berbagi, saling berempati, berinteraksi secara menyenangkan, dan bertanggungjawab terhadap masingmasing perasaan dan perilakunya, serta keluarga bersedia untuk berkolaborasi dalam menyelesaikan masalah sehingga yang berat sama dipikul dan yang ringan sama dijinjing.

Dengan demikian, untuk menjaga stabilitas psikologi keluarga tetap terjaga, maka konsep saling bermu'syarah bil ma'ruf harus senantiasa dijaga atau bahkan ditingkatkan, dengan menjalin hubungan relasi yang baik antara suami, istri dan anak. Pola relasi komunikasi yang dapat 
ditampilkan adalah pola komunikasi yang dapat membentuk suatu pola hubungan yang harmonis, yaitu dimana masing-masing partisipan dapat beralih peran, pada waktu tertentu komunikator dapat berperan sebagai komunikan dan begitu pula sebaliknya, serta masning-masing partisipan memiliki hak suara yang sama dan tidak boleh digantikan oleh orang lain (Mulyana, 2007).

3. Aspek sosiologis

Bukan hanya soal psikologis keluarga yang terdampak, namun sosiologis keluarga, baik itu hubungan sosial antar satu anggota keluarga dengan anggota keluarga yang lainnya maupun antara keluarga dengan masyarakat, sangat berdampak. Padahal sebagaimana yang banyak diketahui bahwa manusia sebagai makhluk sosial untuk mempertahankan hidupnya harus hidup bersosial dengan cara menjalin relasi dan interaksi antar manusia, baik antara individu dengan individu atau kelompok serta antar kelompok (Hariyono, 2009: 179). Oleh karena kondisi ruang gerak sosial sangat terbatas dan supaya kualitas keluarga yang mașlahah itu tetap terbentuk, maka dengan menerapkan konsep mașlahah ta'awun anggota keluarga saling menunjukkan sikap untuk saling memberikan bantuan atau kontribusi, saling memberikan dukungan dan motifasi antara suami/ayah dan istri/ibu, antara orang tua dan anak, serta antara keluarga dengan masyarakat sekitarnya.

4. Aspek ekonomi

Aspek ekonomi menjadi aspek yang perubahannya begitu sangat signifikan dirasakan oleh hampir semua keluarga. Tidak sedikit pula suami yang kehilangan pekerjaannya. Hal ini sebagaimana tercatat di Kemnaker (Kementerian Ketenagakerjaan) hingga 31 Juli 2020 bahwa masyarakat yang terdampak akibat pandemi covid-19 telah mencapai 3,5 juta orang. Ini tentu bukan angka yang sedikit, jika dihitung dari awal pemberlakuan PSBB di Indonesia, berarti hingga juli sudah sekitar 5 bulan. Dalam kurun waktu 5 bulan saja sudah 3,5 juta orang yang kehilangan penghasilannya.

Melihat Keadaan demikian tidak menutup kemungkinan akan menjadikan ketahanan keluarga goyah. Dan sepertinya alasan ekonomi juga menjadi penyebab banyaknya pengajuan perceraian di Pengadilan Agama di seluruh Indonesia. Dengan memberlakukan konsep mașlahah dalam pandangan qira'ah mubadalah, setidaknya akan memberikan sedikit pemahaman dalam melihat problematika masyarakat. Dalam kondisi pandemi, untuk menjaga kualitas kemaslahan keluarga, maka dalam konteks ekonomi ini, keluarga semestinya mengedapnkan konsep ta'awun, mu'asyarah bil ma'ruf, dan musyawarah.

Sebagai gambaran akan penulis contohkan, suami kehilangan pekerjaan dan istri pun juga kehilangan pekerjaan. Kondisi seperti ini tentu sungguh menjadikan perekonomian keluarga menjadi mati total. Akan tetapi, keluarga yang berusaha untuk menyelamatkan keluarga agar tetap menunjukkan mașlaḥah, maka dengan menerapkan konsep-konsep kesalingan dalam keluarga sebagaimana penulis jelaskan di atas, setidaknya dapat 
digunakan "senjata" untuk membentengi keluarga dari berbagai terpaan di masa pandemi. Keluarga yang menerapkan konsep kesalingan (mubadalah), tidak akan ada situasi yang saling menuntut antara satu anggota dengan anggota lainnya, semuanya akan saling memahami kondisi masingmasing anggota keluarga. Suami kehilangan pekerjaan, dan istri dengan kemampuan berdagangnya, misalnya, maka dengan menerapkan konsep mu'awanah (saling membantu) suami dapat membantu istri berdagang. Dan konsep-konsep ini bisa diberlakukan dalam kondisi seperti apapun, baik kondisi normal maupun tidak normal, seperti masa pandemi covid ini.

\section{KESIMPULAN}

Dari penjabaran di atas dapat disimpulkan bahwa konsep keluarga mașlahah dalam perspektif qira'ah mubadalah pada prinsipnya lebih mengutamakan pada konsep kesalingan, artinya tidak ada pihak yang bersifat superior dan inferior di dalam keluarga. Sebagai indikator keluarga mașlahah dalam kerangka qira'ah mubadalah dapat ditampilkan setidaknya dengan beberapa prinsip, yakni prinsip zawaj (saling berpasangan), prinsip mu'adalah (saling adil), prinsip muwazanah (saling seimbang), prinsip mu'awanah (saling membantu), prinsip musyawarah (saling berembug), prinsip taradhin min huma (saling rela), dan prinsip mu'asyarah bil ma'ruf (saling berkomunikasi/bergaul dengan baik). Dengan memperhatikan konsep dan prinsip yang disebutkan tersebut, penulis berasumsi bahwa konsep keluarga mașlahah dalam kerangka mubadalah ini mempunyai relevansi yang cukup signifikan jika diterapkan oleh setiap keluarga, terkhusus di masa pandemic Covid-19 seperti sekarang ini.

\section{DAFTAR PUSTAKA}

Abu Ishak Asy-Syatibi. (n.d.). alMuwafaqat fi Ushul asy-Syari'ah (II). Kairo: Mustafa Muhammad.

Az-Zuhaily, W. (1986). Usul al-Figh alIslamy. Damaskus: Dar Al-Fikr.

Efendi, F., \& Khamami. (1999). Membangun Masyarakat Madani: Melalui Khutbah dan Ceramah. Jakarta: Nuansa Madani.

Ensiklopedi NU. (n.d.). Keluarga Mașlaḥah. Http:/ / www.nu.or.id/a,publicM,dinamic-S,detail-ids,44-id,40414Lang,idc,nasionalt,Keluarga+Macla\%ah-.phpx.

Hariyono. (2009). Ilmu Sosial dan Budaya Dasar. Semarang: Mutiara Wacana.

Kodir, F. A. (2019). Qira'ah mubadalah. Yogyakarta: Ircisod.

Lestari, S. (2014). Psikologi Keluarga: Penanaman Nilai \& Penanganan Konflik dalam Keluarga. Jakarta: Prenamedia Group.

Mursalin, S. (2007). Menolak Poligami: Studi Tentang Undang-Undang Perkawinan dan Hukum Islam. Yogyakarta: Pustaka Pelajar.

Najib, A. M., Azhar, E. S., Amilia, F., \& Wahid, W. G. A. (2005). Membangun Keluarga Sakinah dan Maslahaah Panduan bagi Keluarga Islam Modern. Yogyakarta: PSW UIN Sunan Kalijaga.

Nasution, K. (2013). Hukum Perkawinan 1: Dilengkapi Perbandingan UU Negara Muslim Kontemporer. Yogyakarta: 
ACAdeMIA + TAZZAFA.

Nasution, K. (2018). Menghapus

Kekerasan dalam Rumah Tangga dengan Kajian Normatif-Yuridis: Analisis Interdisipliner dengan Pembedaan Nash Objektif Dan Temporal. JURIS (Jurnal Ilmiah Syariah), 17(1), 35-46. https://doi.org/10.31958/juris.v17i1. 1000

newsdetik. (2020). Perceraian di Pulau Jawa. Syafe'i, Rahmat. (1999). Ilmu Ushul Fiqih. Bandung: CV. Pustaka Setia.

Mahfudh, S. (2001). MUI dan Ihtiar Mewujudkan Keluarga Mașlahah di Pati. Musyawarah Daerah VI MUI Kabupaten Pati.

Shihab, Q. (2005). Tafsir al-Misbah: Pesan, Kesan dan Keserasian al-Qur'an (V). Jakarta: Lentera Hati.

UNINUS. (n.d.). Keadilan, Kesalingan, dan Keseimbangan Fondasi Utama Keluarga Mașlahah.

Wals, F. (2006). Strengthening Family Resilience. New York: The Guilford Press.

Werdiningsih, W. (2020). Penerapan Konsep Mubadalah dalam Pola Pengasuhan Anak. Ijougs: Indonesian Journal of Gender Studies, Vol. 1(Nomor 1), $1-16$. http://jurnal.iainponorogo.ac.id/ind ex.php/ijougs/article/view/2062/12 66

Yusdani. (2015). Menuju Fiqh Keluarga Progresif. Yogyakarta: Kaukaba Dipantara.

Yusdani, \& Muntoha. (2013). Keluarga Mașlaḥah. Yogyakarta: PSI UII dan KIAS. 